\title{
Pola Pemberian MP-ASI pada Balita Usia 6-24 Bulan
}

\author{
Yuliati Amperaningsih ${ }^{1}$, Siska Aulia Sari ${ }^{2}$, Agung Aji Perdana ${ }^{3}$ \\ ${ }^{1}$ Prodi Keperawatan Tanjungkarang, Politeknik Kesehatan Tanjungkarang, Indonesia \\ ${ }^{2}$ Dinas Kesehatan Provinsi Lampung, Lampung, Indonesia \\ ${ }^{3}$ Fakultas Kesehatan Masyarakat, Universitas Malahayati Bandar Lampung, Indonesia \\ Email: siska.aulia17@gmail.com
}

\begin{abstract}
Pattern of Breastfeeding in Toddlers Age 6-24 Months. WHO in WHA reported that $60 \%$ of direct and indirect infant deaths were caused by malnutrition and $2 / 3$ of these deaths were associated with poor feeding practices in infants and children. Based on PSG results in 2016, Lampung and Bandar Lampung acute and chronic community nutritional problems (short prevalence $\geq 20 \%$ and thin $\geq 5 \%$ ). The purpose of this study is to know the pattern of giving of breast milk in infants aged 6-24 months in the work area of Puskesmas Kota Baru New Town Bandar Lampung in 2017. This research is a qualitative research with phenomenology approach. Information obtained by conducting in-depth interviews, FGD, and observation. Informants in this study consisted of 5 main informants, 2 informants triangulation. The results showed that the form of MP-ASI have given for the age of 6-8 months and 12-24 months was appropriate but for 9-11 months age was not yet appropriate. The amount given is still less than the need with the frequency of giving 2-3 times a day plus 2 times a distraction. Type of MP-ASI is a local MP-ASI and MP-ASI manufacturer. How to serve in the form of dilute and liquid who fed by the mother. Raw food ingredients are stored separately with cooked foods. Feeding meals and suggestions are from their own mothers. Advice for MP-ASI counselors to provide regular and recorded counseling so that the stages and success of counseling can be evaluated.
\end{abstract}

Keywords: Given Pattern, MP-ASI, Toddler

\begin{abstract}
Abstrak: Pola Pemberian MP-ASI pada Balita Usia 6-24 Bulan. WHO dalam WHA melaporkan bahwa $60 \%$ kematian balita langsung maupun tidak langsung disebabkan oleh kurang gizi dan 2/3 dari kematian tersebut terkait dengan praktik pemberian makanan yang kurang tepat pada bayi dan anak. Berdasarkan hasil PSG tahun 2016, Provinsi Lampung dan Kota Bandar Lampung memiliki masalah gizi masyarakat akut dan kronis (prevalensi pendek $\geq 20 \%$ dan kurus $\geq 5 \%$ ). Tujuan penelitian ini adalah untuk mengetahui pola pemberian MP-ASI pada balita usia 624 bulan di wilayah kerja Puskesmas Susunan Baru Kota Bandar Lampung tahun 2017. Penelitian ini merupakan penelitian kualitatif dengan pendekatan fenomenologi. Informasi diperoleh dengan melakukan wawancara mendalam, FGD dan observasi. Informan dalam penelitian ini terdiri dari 5 informan utama, 2 informan triangulasi. Hasil penelitian menunjukkan bahwa bentuk MP-ASI yang diberikan untuk usia 6-8 bulan dan 12-24 bulan telah sesuai namun untuk usia 9-11 bulan belum sesuai. Jumlah yang diberikan masih kurang dari kebutuhan dengan frekuensi pemberian 23 kali sehari ditambah 2 kali selingan. Jenis MP-ASI adalah MP-ASI lokal dan MP-ASI pabrikan. Cara penyajian dalam bentuk encer dan berkuah yang disuapi oleh ibu. Bahan makanan mentah disimpan secara terpisah dengan makanan matang. Makanan pantangan dan anjuran berasal dari ibu sendiri. Saran untuk konselor MP-ASI agar dilakukan pemberian konseling secara berkala dan tercatat sehingga tahapan dan keberhasilan konseling dapat dievaluasi.
\end{abstract}

Kata kunci: Pola Pemberian, MP-ASI, Balita

World Health Organization (WHO) dalam Resolusi World Health Assembly (WHA) nomor 55.25 tahun 2002 tentang Global Strategy of Infant and Young Child Feeding melaporkan bahwa $60 \%$ kematian balita langsung maupun tidak langsung disebabkan oleh kurang gizi dan $2 / 3$ dari kematian tersebut terkait dengan praktik pemberian makanan yang kurang tepat pada bayi dan anak. Pemberian makan yang tidak tepat dan terlalu dini mengakibatkan banyak anak mengalami gangguan pertumbuhan dan menderita kurang gizi (Kemenkes RI, 2011). Secara nasional, prevalensi berat-kurang berdasarkan hasil Riskesdas tahun 2013 adalah $19,6 \%$, terdiri dari $5,7 \%$ gizi buruk dan $13,9 \%$ gizi kurang (Kemenkes RI, 2013). 
Masalah kesehatan masyarakat dianggap serius bila prevalensi gizi buruk-kurang antara 20,0-29,0\%, dan dianggap prevalensi sangat tinggi bila $\geq 30 \%$ (WHO, 2010 dalam Kemenkes RI, 2013). Diantara 33 provinsi, Provinsi Lampung berada diantara $15-20 \%$, yang berarti prevalensi gizi berat-kurang berada di atas target nasional $(15,5 \%)$ dan apabila tidak diintervensi dapat mendekati prevalensi tinggi (Kemenkes RI, 2013).

Masalah kesehatan masyarakat sudah dianggap serius bila prevalensi kurus antara 10,0$14,0 \%$, dan dianggap kritis bila $\geq 15,0 \%$ (WHO 2010 dalam Kemenkes RI, 2013). Diantara 16 provinsi yang masuk kategori serius, salah satunya adalah Provinsi Lampung (Kemenkes RI, 2013).

Berdasarkan data hasil Pemantauan Status Gizi (PSG) tahun 2016 Dinas Kesehatan Provinsi Lampung, masalah gizi berdasarkan kelompok umur 0-23 bulan adalah gizi kurang sebesar $12,4 \%$ dan kurus sebesar 7,8\%. Status gizi berdasarkan indeks $\mathrm{BB} / \mathrm{U}<-3$ z-score menurut kabupaten/kota, Kota Bandar Lampung termasuk 3 tertinggi yaitu sebesar $3,8 \%$. Sedangkan status gizi berdasarkan indeks $\mathrm{BB} / \mathrm{U}$ di $<-2$ z-score sebesar 10,9 \% (Kemenkes RI, 2017).

Persentase balita sangat kurus Kota Bandar Lampung berdasarkan hasil PSG Tahun 2016 sebesar $5,1 \%$, termasuk urutan 2 tertinggi yaitu sebesar $6,7 \%$. Untuk persentase balita kurus sebesar 7,7\%. Ini menunjukkan bahwa Provinsi Lampung dan Kota Bandar Lampung memiliki masalah gizi masyarakat akut dan kronis (prevalensi pendek $\geq 20 \%$ dan kurus $\geq 5 \%$ ) (Kemenkes RI, 2017).

Berdasarkan hasil evaluasi program gizi Dinas Kesehatan Kota Bandar Lampung Tahun 2016, Puskesmas dengan prevalensi BGM dan prevalensi $2 \mathrm{~T}$ di atas target adalah Susunan Baru $1 \%$ dan 6,2\% (Dinkes Kota Bandar Lampung, 2016). Terjadinya kondisi kekurangan zat gizi disebabkan oleh pemenuhan kebutuhan zat gizi yang tidak seimbang. Hasil SDT (Survey Diet Total) 2014 menggambarkan pola konsumsi masyarakat masih tinggi karbohidrat, tidak cukup mengkonsumsi sayur dan buah, kualitas protein masih rendah, konsumsi makanan dan minuman berkadar gula tinggi, garam tinggi dan lemak tinggi (Kemenkes RI, 2014).

Survei pendahuluan pada seorang ibu yang memiliki balita usia 14 bulan memberikan gambaran yang serupa dengan pernyataan konselor MP-ASI di Dinas Kesehatan Provinsi Lampung. Ibu memberikan sarapan berupa 1 keping biskuit yang dilumatkan dengan air. Pada pukul 10.00 WIB, ibu memberikan $2 \mathrm{sdm}$ nasi yang diberi kaldu ayam dan abon, namun tidak dihabiskan oleh anak. Untuk makan siang, ibu memberikan nasi ditaburi abon. Pada pukul 16.00 WIB ibu kembali memberikan 1 keping biskuit yang dilumatkan dengan air. Ibu masih memberikan ASI sesuai keinginan anak.

Berdasarkan latar belakang di atas, maka penulis tertarik untuk meneliti pola pemberian MP-ASI balita usia 6-24 bulan di wilayah kerja Puskesmas Susunan Baru Kota Bandar Lampung tahun 2017.

Status gizi balita sangat dipengaruhi oleh kecukupan asupan gizi, status infeksi dan pola asuh. Kota Bandar Lampung termasuk kota yang memiliki masalah gizi masyarakat akut dan kronis dengan prevalensi gizi kurang 10,9\% dan kurus 7,7\%. Puskesmas Susunan Baru merupakan puskesmas dengan prevalensi balita $2 \mathrm{~T}$ dan BGM diatas target yaitu sebesar $6,2 \%$ dan $1 \%$. Dari uraian di atas peneliti ingin mengetahui dan menganalisa pola pemberian MP-ASI pada balita usia 6-24 bulan di Puskesmas Susunan Baru Kota Bandar Lampung.

\section{METODE}

Penelitian ini merupakan penelitian kualitatif dengan pendekatan fenomenologi. Informasi diperoleh dengan melakukan wawancara mendalam, FGD dan observasi.

Pemilihan informan pada penelitian ini dilakukan secara purposive sampling, terdiri dari informan kunci yaitu Konselor MP-ASI, informan utama yaitu ibu dan informan tambahan yaitu kader.

\section{HASIL}

\section{Informasi Menyusu Anak}

Informan masih memberikan ASI sesuai keinginan anak dan lebih sering malam hari, seperti yang dikutip dari hasil wawancara berikut:

"Ga keitung, sering banget... ya malam itu ngegandil aja, bu ..."(I.03)

Hasil FGD menggambarkan bahwa menurut informan usia pertama kali diberikan makanan selain ASI adalah 6 bulan dan setelah 6 bulan, seperti kutipan hasil FGD berikut:

$$
\text { “setelah } 6 \text { bulan...”(I.04) }
$$


Praktik pemberian makan yang pertama kali diberikan selain ASI yang dilakukan informan berupa nasi dicampur pisang kepok yang digiling lalu disaring, biskuit yang dilumatkan dengan air dan bubur pabrikan yang dibeli secara mandiri.

"ini nasi ama pisang... Nasi pake saringan dipenyet-penyet dicampur pisang kepok. Nasinya paling 2 sendok kecil kalo ga 1 sendok kecil, pisangnya $1 / 2$ potong..."(I.02)

Alasan informan memberikan makanan selain ASI dini karena anak menangis, ibu merasa anak tidak kenyang, agar anak tidak rewel, anak menyusu terlalu sering, dan cobacoba saja.

"Orang dek e nangis terus, kayak ga kenyang gitu... makanya tak kasih makan..."(I.01)

\section{Bentuk, Jumlah dan Frekuensi MP-ASI}

\section{a. Pemberian MP-ASI pada Anak yang Mendapat ASI}

Berdasarkan hasil wawancara diketahui pemberian MP-ASI pada usia 7 bulan diberikan bubur nasi dicampur pisang sebanyak 2 sendok makan setiap kali makan yang diberikan 2 kali sehari ditambah 2 kali selingan, usia 9 bulan masih diberikan bubur cerelac sebanyak 2 sendok makan setiap kali makan dan makanan lumat sebanyak 2 sendok makan setiap kali makan yang diberikan 1 kali dalam 2 kali jam makan ditambah 1 kali selingan. Usia 12 bulan telah diberikan makanan keluarga sebanyak 21/2 sendok makan setiap kali makan dengan frekuensi 3 kali sehari ditambah 2 kali selingan dan 20 bulan diberikan makanan keluarga sebanyak 10 sendok makan setiap kali makan dengan frekuensi 3 kali sehari ditambah 2 kali selingan, seperti kutipan hasil wawancara berikut:

"Pagi makan cerelac, kan dah tak oplos beberapa hari ini. Kalau pagi makan cerelac, kalau sore nasi... jam 7 udah tak dulang. Abis tu makan roti.Cerelac nya 2 sendok makan.Siang dia makan roti paling sepotong, roti regal sachetan. Siang ga makan sama sekali... sore kemaren setengah empat makan nasi 2 sendok makan digiling dicampur ama wortel ama itu...kentang. Tahu udah dikasih, tahu putih itu... siang cuma nyusu. Abis makan kan dia minum air putih. Ga lama dia tidur ...ya pas tidur itu dia nyusu... sekitar jam 11 udah pada tidur..."(I.01)

\section{b. Makanan Anak Sakit}

Berdasarkan hasil wawancara diketahui pemberian makan anak sakit oleh 1 informan tidak berbeda dengan pemberian makan saat anak tidak sakit, 3 informan memberikan makan lebih sedikit dan 1 informan memberikan ASI lebih sering.

"Sama aja yang biasa itu... dia sakit juga makannya tetap biasa, cuma kok badannya langsung turun padahal makannya biasa..."(I.01)

\section{c. Cara Penyajian MP-ASI}

Berdasarkan hasil wawancara, informan cenderung memberikan bubur encer. Berikut hasil wawancara mengenai cara penyajian MPASI:

"Encer... berkuah, kalau kering ga ketelen... yang penting ada ini nya lah, basah... piringnya persis kayak gitu (menunjuk gambar mangkok peneliti), saya sendiri (yang menyuapi)..."(I.01)

\section{d. Teknik dan Strategi Pemberian MP-ASI}

Berdasarkan hasil wawancara diketahui 1 informan mengatur makan anak berdasarkan persepsi informan dimana informan hanya memberikan makan waktu pagi dan sore dikarenakan anak pernah diberi makan pada siang hari namun tidak mau sehingga informan tidak lagi memberikan makan pada siang hari, 3 informan mengatur waktu makan anak dan 1 informan tidak melakukan pengaturan waktu makan, seperti kutipan wawancara berikut:

"Cuma itu pagi ama sore aja.pernah itu ga mau kalo siang, digendong sama mbahnya, didulang tetap ga mau..."(I.01)

Kebiasaan anak dalam menghabiskan makanannya tergambar dalam hasil kutipan wawancara berikut:

"Segitu aja kadang ga habis... (ibu menunjuk dasar mangkuk saat ditanya berapa banyak porsi makan anak)..."(I.02) 
Yang dilakukan informan jika anak tidak menghabiskan makannya terlihat dari hasil kutipan wawancara berikut:

\section{"Makanannya dibuang, nanti dibuatin lagi..."(I.04)}

Berdasarkan hasil observasi dapat diamati beberapa hal, yaitu informan melakukan kontak mata dengan anak dan memberikan belaian pada anak saat menyusu. Ibu menyuapi anak dengan sabar namun tidak mengajak anak berbicara ataupun membujuk anak. Bentuk komunikasi ibu ketika menyuapi adalah meminta anak menyuap dan menelan makanannya.

Peneliti mengamati informan berkomunikasi dengan anaknya. Berdasarkan hasil observasi, anak merasa tenang dan nyaman bersama informan. Ketika anak menangis, informan menyusui anak dan memberi anak mainan. Selama observasi tidak terlihat anak meronta atau pun bertindak agresif.

\section{e. Status Infeksi Anak}

Hasil wawancara informan menyatakan bahwa anak mereka pernah mengalami sakit 2-3 kali dalam 1 bulan terakhir yaitu demam, batuk, pilek, sariawan, campak.

$$
\text { “Iya... sariawan, panas..."(I.03) }
$$

\section{f. Keamanan Pangan Dalam Pembuatan MP- ASI}

Berdasarkan hasil wawancara dan observasi diketahui 3 informan menyimpan bahan makanan mentah dan makanan yang belum habis di kulkas, 1 informan menyimpan bahan makanan mentah digantung di rak piring dan 1 informan meletakkan di meja, sedangkan untuk makanan yang belum habis informan menyimpannya didalam tudung saji, seperti kutipan wawancara berikut:

“Di kulkas...”(I.01)

"Di dalam tudung saji... bahan makan mentah di dapur... ga ada kulkas jadi naroknya gantung-gantung di rak..."(I.02)

Berdasarkan hasil observasi diketahui informan menggunakan penyedap makanan dalam pengolahan makanan dan ada 1 informan yang meletakkan bahan kimia berbau tajam berdekatan dengan bahan makanan.

\section{g. Karakteristik Keluarga}

Usia Kepala Keluarga berkisar antara 30 tahun sampai 39 tahun. Pendidikan formal yang pernah diikuti adalah 1 orang tidak lulus SD, 1 orang lulus SD, 1 orang lulus SMP dan 2 orang lulus SMU/SMK. Semua kepala keluarga berasal dari suku jawa. Pendapatan keluarga berasal dari upah yang diterima dari bekerja sebagai pedagang, buruh harian, buruh bangunan, teknisi mesin dan supir toko dengan besar penghasilan paling rendah sebesar Rp. 400.000 per bulan dan paling tinggi sebesar Rp. 3.000 .000 per bulan dengan jumlah anggota keluarga berkisar antara 3 orang sampai 5 orang.

Berdasarkan hasil wawancara, yang memutuskan menu dan yang memasak makanan adalah informan. Sedangkan berapa kali memasak dalam sehari, 4 informan memasak 1 kali sehari dan 1 informan memasak 2 kali sehari. Berikut kutipan wawancara:

$$
\text { “2 kali, pagi dan sore...”(I.O2) }
$$

\section{h. Kondisi Sosial Budaya}

Kondisi sosial budaya berkenaan dengan kosep tentang makanan adalah nilai berkenaan dengan makna yang ditanamkan masyarakat yang membentuk pola pikir informan tentang pelabelan makanan yang dianjurkan dan makanan pantangan. Berdasarkan hasil wawancara dan FGD, makanan pantangan dan makanan yang dianjurkan berasal dari persepsi dan pengalaman ibu. 2 Informan tidak memberikan makanan yang berminyak karena takut batuk dan 1 informan berdasarkan konsep rasa yaitu pedas, asam dan asin, seperti kutipan wawancara berikut:

"Kalo ga boleh itu... kerupuk-kerupuk emang ga boleh, batuk..."(I.01)

"kalo makan yang pedes-pedes belum dikasih, terlalu kecut, terlalu asin... takut mencret..."(I.02)

Informan tidak memberikan makanan khusus namun memberikan makanan yang disukai anak, seperti kutipan wawancara berikut:

"Nasi, pisang, roti... pisang habis direbus itu kan diulek terus disuapin, huu... seneng bener dia, mbak..."(I.04) 


\section{PEMBAHASAN}

\section{ASUPAN GIZI}

\section{a. Informasi Menyusu Anak}

Hasil penelitian menunjukkan bahwa informan memberikan ASI sesuai keinginan anak dan lebih sering di malam hari. Cara pemberian makanan yang baik dan benar adalah menyusui bayi secara eksklusif sejak lahir sampai umur 6 bulan dan meneruskan menyusui anak sampai umur 24 bulan. Melanjutkan pemberian ASI hingga usia 24 bulan dapat memberikan perlindungan dari berbagai penyakit dan mempererat ikatan kasih sayang yang bermanfaat bagi perkembangan jiwa anak (Kemenkes RI, 2011).

Berdasarkan hasil penelitian diperoleh gambaran praktik pemberian makanan pendamping ASI secara dini dimulai pada usia 4 bulan dan diatas 5 bulan. Beberapa informan memberikan nasi yang dicampur dengan pisang, beberapa informan memberikan makanan bayi produk industri (cerelac dan sun). Alasan informan memberikan MP-ASI dini karena bayi sering menangis, ibu merasa bayi tidak kenyang dan ingin mencoba memberikan MP-ASI pada bayi serta ibu merasa ASI sudah berkurang.

Alasan pemberian MP-ASI secara dini yang disebabkan karena bayi menangis terus, bayi tidak kenyang dan ingin mencoba memberikan MP-ASI bukan merupakan suatu alasan yang tepat. Menurut Roesli (2001) dalam Saputri (2013) menyatakan bahwa dari $100 \mathrm{ibu}$ yang mengatakan ASI-nya kurang sebenarnya hanya 2 ibu yang ASI-nya betul-betul kurang.

\section{b. Bentuk, Jumlah dan Frekuesi Pemberian MP-ASI}

Berdasarkan hasil penelitian diketahui pemberian MP-ASI telah dilakukan secara bertahap yaitu pada usia 7 bulan diberikan bubur nasi dicampur pisang sebanyak 2 sendok makan yang diberikan 2 kali sehari ditambah 2 kali selingan, namun usia 9 bulan masih diberikan makanan lumat sebanyak 2 sendok makan yang diberikan 2 kali sehari ditambah 1 kali selingan. Usia 12 bulan dan 20 bulan telah diberikan makanan keluarga sebanyak $2^{1 / 2}$ sendok makan dengan frekuensi 3 kali sehari ditambah 2 kali selingan dan 20 bulan telah diberikan makanan keluarga sebanyak 10 sendok makan dengan frekuensi 3 kali sehari ditambah 2 kali selingan.

Anak yang mulai mengkonsumsi makanan pendamping ASI memerlukan waktu untuk membiasakan diri pada rasa maupun tekstur makanan baru tersebut. Pemberian makanan dilakukan secara bertahap baik bentuk, jumlah dan frekuensi. Usia 6-8 bulan selain ASI, bayi diberikan makanan lumat 2-3 sendok makan secara bertahap bertambah hingga mencapai $1 / 2$ gelas atau $125 \mathrm{cc}$ setiap kali makan dengan frekuensi 2-3 kali sehari ditambah 1-2 kali selingan (Kemenkes RI, 2011).

Usia 9-11 bulan diberikan makanan lembik sebanyak $175 \mathrm{cc}$ dengan frekuensi 3-4 kali sehari ditambah 1-2 kali selingan. Anak yang berusia 12-24 bulan dapat diberikan makanan keluarga sebanyak 3/4-1 mangkuk atau $250 \mathrm{cc}$ dengan frekuensi 3-4 kali sehari ditambah 2 kali selingan (Kemenkes RI, 2011).

Berdasarkan hasil wawancara dan observasi ditemukan jenis MP-ASI yang diberikan pada anak adalah MP-ASI lokal yang diolah sendiri oleh ibu dan MP-ASI pabrikan yang dibeli secara mandiri yang diberikan bergantian dalam sehari.

Informan memberikan bahan makanan yang tersedia di daerah setempat dengan harga yang terjangkau. Jenis makanan pendamping ASI yang diberikan informan memiliki variasi yang sama dalam jangka waktu yang cukup lama. Pemberian MP-ASI dengan bahan yang sama sebaiknya dilakukan selama 4 hari berturut-turut dengan porsi yang sama kepada anak. Hal ini dilakukan untuk mengetahui reaksi alergi dan penyerapan yang maksimal dari asupan tersebut. Selain itu saluran pencernaan bayi memerlukan waktu tertentu untuk mengeluarkan enzim khusus agar bisa menyerap manfaat protein hewani tersebut (Bayu, 2014).

Seiring dengan bertambahnya umur, pertumbuhan anak bertambah dan jumlah makanan yang dibutuhkan juga meningkat. Ibu secara bertahap menambah jumlah porsi makanan dalam setiap kali makan hingga anak dapat menghabiskan porsi makan sesuai usianya, mengolah dan menyajikan makanan dengan berbagai variasi menu, tampilan, dan rasa sehingga anak merasa tertarik dan mau untuk menghabiskannya.

Berdasarkan hasil penelitian diperoleh gambaran komposisi bahan makanan yang diolah merupakan komposisi MP-ASI yang sederhana dimana informan mengolah makanan pokok, protein hewani atau protein nabati dan sayuran atau buah; dan komposisi MP-ASI yang sangat sederhana dimana informan hanya memberikan makanan pokok dengan sayuran atau makanan pokok dengan protein hewani atau protein nabati. Semua bahan makanan mengandung energi, terutama bahan makanan pokok. Walaupun 
makanan pokok juga mengandung protein dan zat gizi lainnya namun tidak dapat memenuhi seluruh kebutuhan zat gizi. Tidak ada satu jenis bahan makanan yang mengandung zat gizi lengkap. Oleh karena itu dalam pembuatan MPASI sebaiknya menggunakan berbagai macam bahan makanan (Mahayu, 2014).

Hasil penelitian Hayati (2012) pada etnis Banjar, jenis MP-ASI yang diberikan pada anak pada saat pertama kali adalah MP-ASI hasil pabrikan dengan alasan mudah diperoleh, tidak repot dan mudah menyajikannya, buah pisang yang dikerik dengan sendok, bubur nasi atau nasi yang dilumatkan. Frekuensi pemberian MP-ASI umumnya diberikan 2-3 kali.

Hasil wawancara menunjukkan bahwa saat anak sakit informan memberikan makan yang berbeda dengan makanan yang diberikan ketika anak sehat. Informan menyusui anak lebih sering dari biasanya, memberikan makanan lebih sedikit, lebih berkuah atau encer dan anak menghabiskan makanan lebih sedikit.

Nafsu makan anak yang menderita sakit infeksi mengalami penurunan dari biasanya. Sementara itu anak memerlukan lebih banyak energi dan zat gizi lainnya untuk meningkatkan daya tahan tubuh melawan infeksi. Pemberian makanan lunak dan berkuah dalam porsi kecil yang mudah ditelan dan dicerna namun sering akan mencegah terjadinya kekurangan asupan anak. Oleh karena itu, berikan anak makanan sesuai kebutuhan dengan porsi sedikit demi sedikit namun sering dalam sehari (Kemenkes RI, 2011).

\section{c. Cara Penyajian MP-ASI}

Berdasarkan wawancara dan observasi di lapangan ditemukan bahwa konsistensi pemberian makanan pada usia enam bulan adalah bubur yang dibuat dari nasi yang dicampur dengan pisang dan bubur bayi produk industri (biskuit, cerelac dan sun) yang diberikan dalam bentuk encer. Beberapa anak usia lebih besar menyukai makanan yang berkuah dan beberapa anak lebih menyukai makanan tanpa kuah.

Perbedaan kekentalan makanan akan mempengaruhi pemenuhan kebutuhan energi anak. Bubur yang encer dan makanan yang berkuah mengandung lebih banyak air sehingga membuat anak lebih cepat kenyang dan anak tidak dapat menghabiskan makanannya. Meskipun didalam bubur terdapat makanan bergizi, tetapi hanya sedikit yang dikonsumsi anak yang artinya hanya sedikit yang terserap dalam tubuh anak. Akibatnya anak tidak memperoleh cukup asupan energi yang dibutuhkannya untuk pertumbuhan (Kemenkes RI, 2011).

MP-ASI dapat dibuat menjadi tinggi energi dan kaya zat gizi dengan menambahkan sedikit air sehingga bubur yang dibuat adalah bubur yang kental dan menambahkan sedikit minyak atau lemak. Penambahan sedikit minyak atau lemak membuat bubur lebih kental, lebih lembut, mudah dimakan dan memberikan tambahan energi.

Bubur yang kental akan dapat memenuhi kebutuhan energi anak karena bubur yang kental tidak mengandung banyak air dan tidak membuat anak cepat kenyang sehingga anak mampu menghabiskan semua bubur. Oleh karena itu kebutuhan energinya terpenuhi (Kemenkes RI, 2011).

\section{d. Kondisi Sosial Budaya}

Kondisi sosial budaya berkenaan dengan kosep tentang makanan adalah nilai berkenaan dengan makna yang ditanamkan masyarakat yang membentuk pola pikir informan tentang pelabelan makanan yang dianjurkan dan makanan pantangan (Ibnu, 2016). Makanan pantangan berasal dari persepsi dan pengalaman informan terhadap makanan tertentu. Sedangkan Makanan anjuran merupakan makanan yang disukai anak. Berdasarkan hasil penelitian, menurut informan makanan pantangan adalah makanan yang berminyak seperti kerupuk, gorengan dan makanan yang pedas, terlalu asam dan terlalu asin. Menurut informan makanan yang berminyak akan menyebabkan batuk dan membuat anak tidak mau makan dan makanan yang pedas, terlalu asam dan terlalu asin dapat menyebabkan anak diare. Makanan anjuran secara khusus tidak ada, namun informan memberikan makanan yang disukai anak yaitu makanan yang mampu dihabiskan anak dalam jumlah yang cukup banyak

Triptasari (2009) menjelasan makanan pantangan bagi suku Anak Dalam Sungai Teras adalah pisang lilin dan ikan seluang. Bila dilanggar maka dipercaya akan mengakibatkan sonop api yaitu sakit demam dengan panas tinggi yang tidak segera turun.

\section{POLA ASUH}

\section{a. Teknik dan Strategi Pemberian MP-ASI}

Berdasarkan hasil wawancara diketahui 1 informan mengatur makan anak berdasarkan persepsi informan yaitu pagi dan sore dikarenakan anak pernah diberi makan pada 
siang hari namun tidak mau sehingga informan tidak lagi memberikan makan pada siang hari, 3 informan mengatur waktu makan anak dan 1 informan tidak melakukan pengaturan waktu makan.

Penerapan waktu dan tempat makan secara terus menerus akan membentuk kebiasaan anak. Selain itu ibu dapat mengajarkan anak mengkonsumsi menu seimbang secara perlahan dengan sabar hingga anak dapat menghabiskan makannya.

Berdasarkan hasil penelitian 1 anak selalu menghabiskan makanannya, 4 anak tidak menghabiskan makanannya. Yang dilakukan informan jika anak tidak menghabiskan makannya adalah 2 informan mengharuskan anaknya menghabiskan makanannya, 1 informan mengganti dengan jenis makanan lain dan 2 informan membiarkan saja.

Ibu perlu menyadari isyarat yang ditunjukkan anak, mengartikannya dengan benar, dan meresponnya secara cepat, tepat dan konsisten.Isyarat yang ditunjukkan anak lapar mungkin gelisah, menjangkau makanan atau menangis. Isyarat atau tanda anak tidak ingin makan lagi diantaranya menolak, melepehkan makanannya atau menangis.

Dalam praktik pemberian makan, berikan makanan kepada anak secara perlahan dan sabar, bujuk dan jangan dipaksa. Hal yang dapat dilakukan agar anak dapat menghabiskan makanan sesuai kebutuhannya, ibu dapat mencoba campuran berbagai bahan makanan, rasa dan tekstur agar anak menyukai makanan tersebut.

Saat menyuapi anak, tunggu sampai anak berhenti mengunyah dan suapi lagi setelah beberapa saat, beri makanan yang sudah dipotong kecil sehingga anak dapat belajar memegang dan makan sendiri, kurangi kemungkinan gangguan yang mungkin muncul bila anak cepat merasa bosan dengan makan, usahakan tetap dampingi anak selama makan dan berikan perhatian penuh.

\section{b. Cara Berkomunikasi dan Ungkapan Perasaan}

Berdasarkan hasil observasi terhadap informan, informan melakukan kontak mata dengan anak dan memberikan belaian pada anak saat menyusu.Informan menyuapi anak dengan sabar namun tidak mengajak anak berbicara ataupun membujuk anak.

Peneliti mengamati informan berkomunikasi dengan anaknya. Dimana anak merasa tenang dan nyaman bersama informan. Ketika anak menangis, informan menyusui anak agar tenang dan memberi anak mainan sehingga anak berhenti menangis dan tidak terlihat anak meronta atau pun bertindak agresif.

Kegiatan makan merupakan proses belajar anak dan kesempatan menerima kasih sayang. Dalam proses pemberian makan hal yang utama adalah menciptakan suasana yang menyenangkan sehingga anak tidak hanya mampu menghabiskan makannya, namun juga merasa aman dan gembira. Ketika ibu berbicara dan menatap anak dengan penuh kasih sayang, hubungan emosional ibu dengan anak akan semakin dekat. Oleh karena itu, saat pemberian makan berikan perhatian dan tanggapan positif kepada anak disertai senyum, kontak mata dan kata-kata yang menyemangati. Sehingga kegiatan makan merupakan kegiatan yang menyenangkan yang akan memberikan dampak positif terhadap asupan gizi anak.

\section{c. Keamanan Pangan Dalam Pembuatan MP- ASI}

Keamanan pangan adalah kondisi dan upaya yang diperlukan untuk mencegah pangan dari kemungkinan tiga cemaran, yaitu cemaran fisik, biologis, kimia, dan benda lain yang dapat mengganggu, merugikan, dan membahayakan kesehatan manusia serta tidak bertentangan dengan agama, keyakinan, dan budaya masyarakat sehingga aman untuk dikonsumsi (BPOM, 2004).

Hasil observasi menunjukkan bahwa tempat penyimpanan bahan makanan mentah disimpan di kulkas, menggantung di rak piring dan meletakkannya di meja. Makanan matang yang belum habis disimpan di kulkas, dalam lemari, dan dibawah tudung saji sedangkan makanan basi dibuang keesokan hari.

Tindakan yang dilakukan informan sudah benar, dimana informan memisahkan bahan makanan mentah dan bahan makanan matang. Informan meletakkan makanan matang di tempat yang tertutup sehingga makanan terhindar dari bahaya biologi, dimana serangga seperti lalat dan kecoa tidak dapat mengotori makanan.

Keputusan informan untuk membuang makanan yang sudah basi sangat tepat. Karena makanan yang sudah basi dapat dipastikan telah mengalami pembusukan oleh mikroba dan jika dikonsumsi dapat menyebabkan keracunan bahkan kematian.

Berdasarkan hasil observasi diketahui informan menggunakan penyedap makanan dalam pengolahan makanan, dan ada 1 informan yang meletakkan bahan kimia berbau tajam berdekatan dengan bahan makanan. Pangan yang 
layak dikonsumsi adalah pangan yang tidak busuk, tidak menjijikkan, dan bermutu baik, serta bebas dari tiga cemaran yaitu cemaran biologi, kimia dan cemaran fisik.

Salah satu cemaran kimia yang sering ada dalam pangan adalah bahan tambahan pangan yang melebihi takaran, contoh: pemanis buatan, pengawet, penyedap makanan yang melebihi batas, dan penggunaan bahan berbahaya yang dilarang pada pangan, contoh: Boraks, Formalin, Rhodamin B, Metanil Yellow. Cara pencegahan dari cemaran Kimia yag dapat dilakukan adalah dengan selalu memilih bahan pangan yang baik untuk dimasak atau dikonsumsi langsung (BPOM, 2017).

\section{d. Status Infeksi Anak}

Balita merupakan golongan individu yang mudah terserang penyakit terutama penyakit menular.Jenis-jenis penyakit infeksi yang sering menyerang balita yaitu beringus, ISPA, diare, batuk dan demam (Mustapa, 2013).

Berdasarkan hasil penelitian dapat diketahui anak pernah mengalami 2-3 kali beberapa jenis penyakit infeksi dalam sebulan terakhir. Penyakit yang di alami adalah demam, batuk pilek, sariawan dan campak.

\section{e. Karakteristik Keluarga}

Ukuran pendapatan yang digunakan untuk mengukur tingkat kesejahteraan keluarga adalah pendapatan keluarga yang diperoleh dari bekerja. Pendapatan merupakan faktor yang menentukan kuantitas dan kualitas pangan yang dikonsumsi seseorang. Semakin tinggi tingkat pendapatan maka semakin besar pula persentase pertambahan pembelanjaannya termasuk untuk pangan dari golongan sayur dan buah-buahan serta berbagai jenis pangan lainnya, tetapi pertambahan kuantitas ini tidak selalu memperbaiki susunan menu makanan yang dikonsumsinya (Prasetyo 2004 dalam Muladsih 2011).

Pengambilan keputusan pangan meliputi pengambilan keputusan dalam hal pengaturan menumakanan dan berapa kali ibu memasak. Berdasarkan hasil penelitian, ibu memutuskan menu yang akan dikonsumsi keluarga dan mengolahnya sendiri 1-2 kali sehari. Hasil penelitian Muladsih (2011) menunjukkan bahwa istri dominan memutuskan untuk hal belanja kebutuhan sehari-hari $(44.00 \%)$, dan pemilihan menu makan sehari-hari (38.70\%). Hal tersebut karena istri terbiasa mengurusi hal-hal yang terkait dengan makanan sehari-hari keluarga.

\section{SIMPULAN}

Berdasarkan hasil penelitian dan pembahasan dapat dibuat suatu kesimpulan yang merupakan jawaban dari penelitian, yaitu:

1. Anak masih diberikan ASI. Bentuk MP-ASI yang diberikan untuk usia 7 bulan dan 12 bulan telah sesuai, namun untuk usia 9 bulan masih diberikan makanan lumat. Jumlah yang diberikan masih kurang dari kebutuhan menurut umur dengan frekuensi pemberian 23 kali sehari ditambah 2 kali selingan.

2. Jenis MP-ASI yang diberikan adalah MP-ASI lokal dan MP-ASI pabrikan yang diberikan secara bergantian dalam sehari.

3. Cara penyajian MP-ASI pada usia 6 bulan diberikan dalam bentuk encer. Sedangkan untuk anak usia lebih besar menyukai makanan yang berkuah dan beberapa anak lebih menyukai makanan tanpa kuah dan anak disuapi sendiri oleh ibu.

4. Teknik dan strategi dalam pemberian MP-ASI tergambar dari 1 informan mengatur makan anak berdasarkan persepsi, 3 informan mengatur waktu makan anak dan 1 informan tidak mengaturan waktu makan. Yang dilakukan informan jika anak tidak menghabiskan makannya adalah 2 informan mengharuskan anaknya menghabiskan makanannya, 1 informan mengganti dengan jenis makanan lain dan 2 informan membiarkan saja.

5. Tempat penyimpanan bahan makanan mentah dan makanan matang telah dipisah. Informan menggunakan penyedap makanan, dan ada 1 informan yang meletakkan bahan kimia berbau tajam dekat bahan makanan.

6. Pendapatan keluarga berasal dari upah yang diterima dari bekerja sebagai pedagang, buruh harian, buruh bangunan, teknisi mesin dan supir toko. Jumlah anggota keluarga 3 orang, 4 orang dan 5 orang dimana ibu memutuskan menu yang akan dimasak 1-2 kali sehari.

7. Makanan pantangan berupa makanan yang berminyak seperti kerupuk, gorengan, makanan yang pedas, terlalu asam dan terlalu asin. Sedangkan makanan anjuran secara khusus tidak ada, namun ibu memberikan makanan yang disukai anak.

\section{SARAN}

1. Agar dilakukan konseling MP-ASI secara berkala, yaitu sekali dalam 2 minggu yang dibagi berdasarkan kelompok umur mengenai bentuk, jumlah, variasi dan 
frekuensi sehingga ibu memiliki pengetahuan dalam memberikan MP-ASI pada anaknya sesuai dengan kebutuhan menurut umur.

2. Agar dilakukan pencatatan tentang konseling MP-ASI yang diberikan sehingga

\section{DAFTAR PUSTAKA}

Badan Pengawas Obat dan Makanan RI. 2004. Peraturan Pemerintah Republik Indonesia No.28 Tahun 2004 Tentang Keamanan, Mutudan Gizi Pangan. Jakarta.

Badan Pengawasan Obat dan Makanan, Bidang Informasi Makanan. 2017. Kenali Pangan pada Anak dan Remaja. www.pom.go.id/files/2017/5.kenalipangan. pdf (Diakses pada tanggal 1 Oktober 2017).

Bayu, M. 2014. Pintar ASI dan Menyusui. Jakarta: Panda Media.

Dinas Kesehatan Kota Bandar Lampung. 2016. Evaluasi Program Gizi Dinas Kesehatan Kota Bandar Lampung. Bandar Lampung: Seksi Gizi.

Hayati, Ida. 2012. Pola Pemberian Makanan Pendamping ASI Bayi 6-12 Bulan pada Etnis Banjar di Kelurahan Lerong Ilir. Jurnal Promosi Kesehatan Nusantara Indonesia, Nomor 10 Edisi 10.

Ibnu, I. N., Thaha, A. R. M., \& Jafar, N. 2016. Pola Asuh Pemberian Makanan Pendamping Asi (Mp-asi) pada Ibu Baduta di Tanah Adat Kajang Ammatoa Kabupaten Bulukumba. Media Kesehatan Masyarakat Indonesia, 9(4), 257-263.

Kementerian Kesehatan RI. 2011. Modul Pelatihan Konseling MP-ASI Pedoman Pelatih. Jakarta: Ditjend Bina Gizi dan KIA.

Kementerian Kesehatan RI. 2013. Riset Kesehatan Dasar (RISKESDAS) 2013. Jakarta: Badan Penelitian dan Pengembangan Kesehatan.

Kementerian Kesehatan RI. 2014. Pokok-pokok Hasil Studi Diet Total Survei Konsumsi Makanan Individu 2014. Jakarta: Badan Penelitian dan Pengembangan Kesehatan. tahapan dan keberhasilan konseling yang telah dilaksanakan dapat dievaluasi.

3. Mengadakan kegiatan praktek pembuatan MP-ASI yang sesuai jumlah, dan bentuknya menurut kelompok umur dengan variasi bahan makanan yang beragam.

Kementerian Kesehatan RI. 2017. Hasil Pemantauan Status Gizi (PSG) Provinsi Lampung Tahun 2016. Jakarta: Direktorat Gizi Masyarakat.

Mahayu, P. 2014. Imunisasi dan Nutrisi. Yogyakarta: Penerbit Buku Biru.

Muladsih, Oktavia Rattika. 2011. Pola Komunikasi, Pengambilan Keputusan dan Kesejahteraan Keluarga Jarak Jauh pada Mahasiswa Pascasarjana IPB. [Skripsi]. Fakultas Ekologi Manusia-IPB, Bogor.

Mustapa, Y., Sirajuddin, S., \& Salam, A. 2013. Analisis Faktor Determinan Kejadian Masalah Gizi pada Anak Balita di Wilayah Kerja Puskesmas Tilote Kecamatan Tilango Kabupaten Gotontalo tahun 2013. Jurnal Universitas Hasanuddin Makassar. Makassar. https://core.ac.uk/download/pdf (Diakses pada 21 September 2017).

Saputri, Kiki Chairani. 2013. Alasan Ibu Memberikan Makanan Pendamping ASI (MP-ASI) Dini dengan Pendekatan Health Beliefe Model di Wilayah Kerja Puskesmas Kecamatan Pesanggrahan Jakarta Selatan Tahun 2013. [Skripsi]. Fakultas Kedokteran dan Ilmu Kesehatan, Universitas Islam Negeri (UIN) Syarif Hidayatullah, Jakarta.

Triptasari, Ignatia Dian. 2009. Konsep dan Praktik Ibu dalam Pemberian ASI dan MPASI serta Pemantauan Pertumbuhan Balita di Komunitas Adat Tertinggal (Studi Kualitatif Pada Suku Anak Dalam Sungai Teras Kabupaten Musi Rawas Sumatera Selatan). [Tesis]. Universitas Diponegoro, Semarang. 